\title{
Suppression of Botrytis cinerea sporulation by Clonostachys rosea on rose debris: a valuable component in Botrytis blight management in commercial greenhouses
}

\author{
Marcelo A.B. Morandi, ${ }^{\mathrm{a}, *, 1}$ Luiz A. Maffia, ${ }^{\mathrm{a}, 2}$ Eduardo S.G. Mizubuti, ${ }^{\mathrm{a}}$ \\ Acelino C. Alfenas, ${ }^{a}$ and José G. Barbosa ${ }^{\mathrm{b}}$ \\ a Departamento de Fitopatologia, Universidade Federal de Viçosa (UFV), 36571-000 Viçosa, MG, Brazil

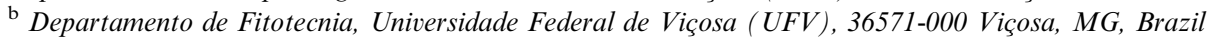

Received 6 May 2002; accepted 25 September 2002

\begin{abstract}
Botrytis blight, caused by Botrytis cinerea $(\mathrm{Bc})$, is an important disease on roses grown in plastic greenhouses in Brazil. Biocontrol with Clonostachys rosea $(\mathrm{Cr})$ applied to leaves and crop debris to reduce pathogen sporulation can complement other control measures for disease management. Two experiments, each with a rose cultivar, were conducted in a plastic greenhouse. For 'Red Success,' four treatments were compared: (1) control; (2) fortnightly sprays of Cr; (3) weekly sprays of mancozeb; and (4) weekly sprays of either $\mathrm{Cr}$ or mancozeb to the lower third of the plants and the debris. For 'Sonia,' treatment 4 was not included. Samples were taken from debris (leaves and petals) at ten 15-day intervals and plated on PCA medium. Sporulation of fungi and incidence of Botrytis blight on buds were assessed. For both cultivars, $\mathrm{C}$ treatments significantly $(P=0.05)$ reduced Bc sporulation. However, disease incidence was not consistently reduced, probably because the applications of $C$. rosea started when Botrytis blight epidemic was advanced and no sanitation practices were performed on nontreated plots. From the present and previous studies, continuous application of $\mathrm{Cr}$ on debris, associated with sanitation practices, has the potential to reduce Bc sporulation and disease incidence in the buds.
\end{abstract}

(C) 2002 Elsevier Science (USA). All rights reserved.

Keywords: Biological control; Botrytis cinerea; Clonostachys rosea; Crop residues; Necrotrophic pathogens; Rosa hybrida

\section{Introduction}

Rose (Rosa hybrida L.) is one of the most appreciated flowers around the world. In Brazil, the crop is grown as a long-term perennial in ground beds in polyethylenecovered greenhouses and the annual production is estimated at 88 million cuttings. Under such conditions, Botrytis blight, caused by Botrytis cinerea Pers.:Fr., is responsible for severe pre- and post-harvest losses. The pathogen produces spreading necrotic lesions on leaves,

\footnotetext{
${ }^{*}$ Corresponding author. Fax: +55-31-3899-2240.

E-mail addresses: mmorandi@enpma.embrapa.br (M.A.B. Morandi), lamaffia@ufv.br (L.A. Maffia).

${ }^{1}$ Present address: EMBRAPA Meio Ambiente, Caixa Postal 69, 13820-000 Jaguariúna, SP, Brazil.

${ }^{2}$ Also corresponding author.
}

shoots, and renewal canes as well as small lesions and blighting of petals of the cut flowers during storage and transit (Elad, 1988; Horst, 1983; Tatagiba et al., 1998). Economic losses are associated chiefly with the development of the disease on the petals.

The abundant $B$. cinerea sporulation on senescent and dead plant tissues contributes to the development and the maintenance of an epidemic within a crop (Hausbeck and Moorman, 1996; Monteiro et al., 1996; Sosa-Alvarez et al., 1995). The suppression of pathogen sporulation on crop debris was proposed as a potential strategy of biological control (Köhl and Fokkema, 1998; Köhl et al., 1995; Sutton and Peng, 1993). The nonpathogenic, saprophytic fungus Clonostachys rosea (Link: Fr.) Schroers, Samuels, Siefert, and W. Gams [Gliocladium roseum Bainier, teleomorph, Bionectria ochroleuca (Schw.) Schroers and Samuels] (Schroers 
et al., 1999) was selected as an efficient antagonist against $B$. cinerea. It suppresses development of the pathogen in plant tissues as well as on the leaf and flower surface of rose and other hosts through competitive colonization of senescing and dead tissues, nutrient competition, and hyperparasitism (Morandi et al., 2001; Sutton et al., 1997; Yu and Sutton, 1997).

In recent studies under controlled conditions, $C$. rosea markedly suppressed sporulation of $B$. cinerea in rose leaves and petals regardless of developmental stage of the tissues, minor wounds, natural densities of microflora, and aphid and mite infestations (Morandi et al., 2000a,b). C. rosea can easily colonize rose leaves under a broad range of microclimatic conditions. Further, it can control sporulation of $B$. cinerea regardless of the time of its arrival in relation to the pathogen (Morandi et al., 2001).

Most studies reporting high efficacy of $C$. rosea against $B$. cinerea on roses were conducted under controlled environments. Thus, information on the effectiveness of its use under commercial greenhouse conditions is lacking. Occasionally, introduction of antagonists that have been highly effective in controlled environments to the phyllosphere of commercially grown plants is only moderately effective and sometimes totally ineffective (Guetsky et al., 2001). Under commercial conditions, the phylloplane is subjected to fluctuating temperatures, relative humidity, surface wetness, gases, and air movement. These conditions may adversely affect the phyllosphere microflora, including the biocontrol agents, or may have an indirect influence by modifying the characteristics of the host tissues, such as the metabolic state and surface chemistry of the leaves (Burrage, 1971; Hannush and Boland, 1996). The objective of this study was to investigate the capacity of $C$. rosea to establish on rose debris and control $B$. cinerea sporulation under a commercial greenhouse environment. This information will contribute to a better understanding of the antagonist's population dynamics under uncontrolled environments and may lead to a reliable and feasible biocontrol strategy for $B$. cinerea on roses.

\section{Materials and methods}

\subsection{Rose plants and cultural procedures}

From January to May 2000 two experiments, each one with a rose cultivar, were conducted in a commercial, plastic-covered greenhouse without climatic control. Three-year-old plants of cultivars 'Sonia' and 'Red Success' were grown in ground beds $(30 \times 1.2 \mathrm{~m})$. There were five beds for 'Sonia' and seven beds for 'Red Success.' The distance between plants on each bed was $0.25 \times 0.50 \mathrm{~m}$.
Fertilization and commercial pesticide were applied according to standard practice of growers in southeast Brazil. Each plant was fertilized with $200 \mathrm{~g}$ N:P:K (4:14:8) in December 1999 and then at two-month intervals. Mite and aphids were controlled by periodic application of malathion (Malatol $500 \mathrm{CE}$ ) and acephate (Orthene 750 BR). Periodic sprays of sulfur (Thiovit BR), folpet (Folpet 500PM), and metalaxyl + chorothalonil (Folio) controlled powdery and downy mildews. The plants were base-irrigated one to three times a week. Buds for marketing were harvested weekly, and the damaged buds and open flowers were cut and left on the ground, as practiced by the growers.

\subsection{Inocula and inoculations}

Botrytis cinerea inoculum existed naturally in the greenhouse at levels sufficient to cause epidemics and was used for quantification of pathogen colonization and sporulation on rose debris. The biological control agent C. rosea (PG-88-710 isolate, Peng and Sutton, 1991) was applied as a spore and mycelium suspension. Mass production of $C$. rosea conidia was obtained on wheat grains, according to a protocol developed by M.A.B. Morandi and L.A. Maffia (unpublished). Wheat grains were steam cooked $(1 \mathrm{~h})$ and autoclaved $\left(121^{\circ} \mathrm{C}\right.$, $30 \mathrm{~min})$. After cooling down, $10 \mathrm{ml} \mathrm{C}$. rosea suspension $\left(10^{7}\right.$ conidia/ml $)$ was applied to $300 \mathrm{~g}$ wheat grains and incubated at $22^{\circ} \mathrm{C}$. After being colonized by the fungus, the grains were slowly air dried for 15 days at $22-25^{\circ} \mathrm{C}$, ground, and sieved on a $1 \mathrm{~mm}$ screen. The final powder averaged $10^{9}$ conidia/g. For spray applications, $10 \mathrm{~g}$ of the powder was suspended on 1 liter of water plus surfactant (Tween $80,0.5 \mathrm{ml} /$ liter water), achieving a final suspension of $10^{7}$ conidia $/ \mathrm{ml}$. The suspension of $C$. rosea was applied at the rate of 1 -liter suspension $/ 10 \mathrm{~m}^{2}$ by a hand spray directed toward the rose debris on the bed surface.

\subsection{Treatments and samples collection}

The experiments were conducted in a complete randomized design with three replications. Experimental plots were $3 \times 1.2 \mathrm{~m}$ wide ( 24 plants $/$ plot) and were $1.5 \mathrm{~m}$ apart. One bed on each side of the greenhouse was kept as border.

For 'Red Success' there were four treatments: (i) application of C. rosea (Cr) biweekly; (ii) application of mancozeb weekly at a ratio of $200 \mathrm{~g}$ c.f. per 100 liter of water (MC); (iii) application of C. rosea and mancozeb $(\mathrm{CrM})$ in alternate weeks; and (iv) water control (CK). For 'Sonia,' the same treatments were applied, except CrM.

For estimation of $B$. cinerea and $C$. rosea colonization and sporulation rate on rose debris and the suppression of $B$. cinerea sporulation by $C$. rosea, six 
sub-samples of 20-30 fallen yellowish leaves and/or recently fallen petals were taken from the surface of each plot at 13-15 day intervals. Twelve disks of $1-\mathrm{cm}$ diameter were cut from each sub-sample and placed on paraquat-chloramphenicol-agar medium (PCA) in petri dishes (Peng and Sutton, 1991). The percentage of disks with $B$. cinerea and/or $C$. rosea sporulation was estimated 7-10 days after incubation at $22 \pm 2{ }^{\circ} \mathrm{C}$ and $12-\mathrm{h}$ photoperiod. A sample collection was performed prior to treatment applications to quantify $B$. cinerea inoculum and to check for the presence of any native strain of $C$. rosea in the experimental area.

A sample of 20 rose buds at harvest stage was taken from each plot at 13-15 day intervals to evaluate Botrytis blight incidence. A bud was considered diseased if there was at least one fleck spot on each external petal.
In the same manner as used for sporulation evaluation, a sample was collected prior to treatment applications.

\subsection{Weather data}

During the period of the experiment, air temperature and relative humidity were monitored with a hygrothermograph. It was kept in a white, wooden shelter placed inside the rose canopy at a height of about $1.5 \mathrm{~m}$. Rainfall was measured with a rain gauge placed outside the greenhouse.

The hourly values of air temperature and relative humidity were used to calculate the daily mean temperature, the mean relative humidity, and the daily maximum and minimum temperatures and relative humidity. The vapor pressure deficit (VPD) was calculated for each

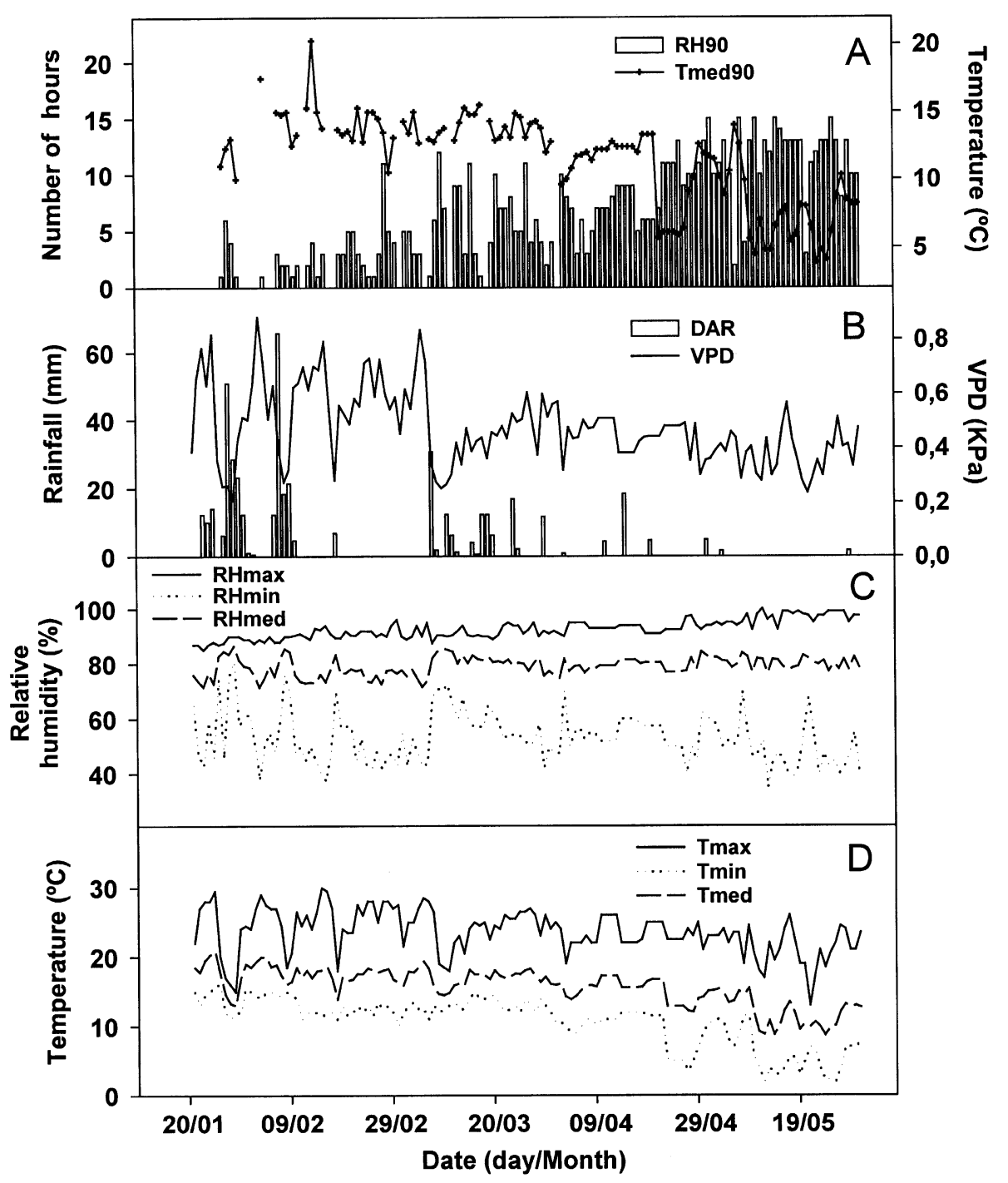

Fig. 1. Climatic variables registered in the greenhouse during the period of the experiment. (A) Daily number of hours with $\mathrm{RH}>90 \%$ (RH90) and the average temperature during RH90 ( $\left.T_{\text {med }} 90\right)$; (B) daily accumulated rainfall outside the greenhouse (DAR) and daily vapor pressure deficit average (VPD); (C) maximum, medium, and minimum daily relative humidity $\left(\mathrm{RH}_{\max }, \mathrm{RH}_{\text {med }}\right.$, and $\mathrm{RH}_{\min }$, respectively); (D) maximum, medium, and minimum daily temperature $\left(T_{\max }, T_{\operatorname{med}}\right.$, and $T_{\min }$, respectively). 
hour and a daily average obtained by the following equation: $\quad \mathrm{VPD}=0.6108 \mathrm{e}^{17.269 T /(T+237.3)}(1-\mathrm{RH} / 100)$; where, $T$ is the temperature $\left({ }^{\circ} \mathrm{C}\right)$ and $\mathrm{RH}$ is the relative humidity (\%) (Snyder and Shaw, 1984).

\subsection{Data analysis}

Data for fungal sporulation and Botrytis blight incidence on rose buds were examined by analysis of variance (ANOVA) (GLM Procedures, SAS Institute, Cary, NC). Since there was no significant effect of subsampling in each plot, the average value of each replication was used for subsequent analysis. The area under the fungal sporulation curve (AUFSC) was calculated for both $C$. rosea and $B$. cinerea on 'Sonia' and 'Red Success.' The treatment means were compared by the protected least significant difference test (PLSD; Snedecor and Cochran, 1989).

\section{Results}

\subsection{Weather}

From January to May 2000, most days had weather conditions favorable to Botrytis blight development inside the greenhouse (Fig. 1). Daily average temperature varied from 15 to $20^{\circ} \mathrm{C}$. Maximum temperature ranged from 23 to $29^{\circ} \mathrm{C}$ and minimum temperature from 10 to $13^{\circ} \mathrm{C}$. Relative humidity remained above $85 \%$ for at least $10 \mathrm{~h}$ on $70 \%$ of days, and rainfall was recorded on $28 \%$ of the days. The average daily VPD ranged from 0.2 to $1.0 \mathrm{kPa}$ and was favorable to $B$. cinerea development on most of the days during the experiments.

\subsection{Sporulation of Botrytis cinerea and Clonostachys rosea on rose debris}

Sporulation intensity and AUFSC of B. cinerea on rose debris of 'Sonia' and 'Red Success' were consistently reduced by $30-50 \%$ on plots treated with $C$. rosea or $C$. rosea plus mancozeb (Figs. 2A, B and 3A, B). Compared to the control, weekly applications of mancozeb only moderately affected pathogen sporulation on 'Red Success' (Figs. 2A and 3A) and did not affect sporulation on 'Sonia' (Figs. 2B and 3B).

Sporulation intensity and AUFSC of $C$. rosea increased steadily on the plots treated with $C$. rosea $(\mathrm{Cr})$ or in combination with mancozeb $(\mathrm{CrM})$. In the $\mathrm{CrM}$ treatment, a slight reduction $(10-15 \%)$ on $C$. rosea sporulation was observed (Figs. $2 \mathrm{C}$ and $3 \mathrm{C}$ ), but the capacity of the antagonist to reduce $B$. cinerea sporulation was not affected (Figs. 2A and 3A). C. rosea was

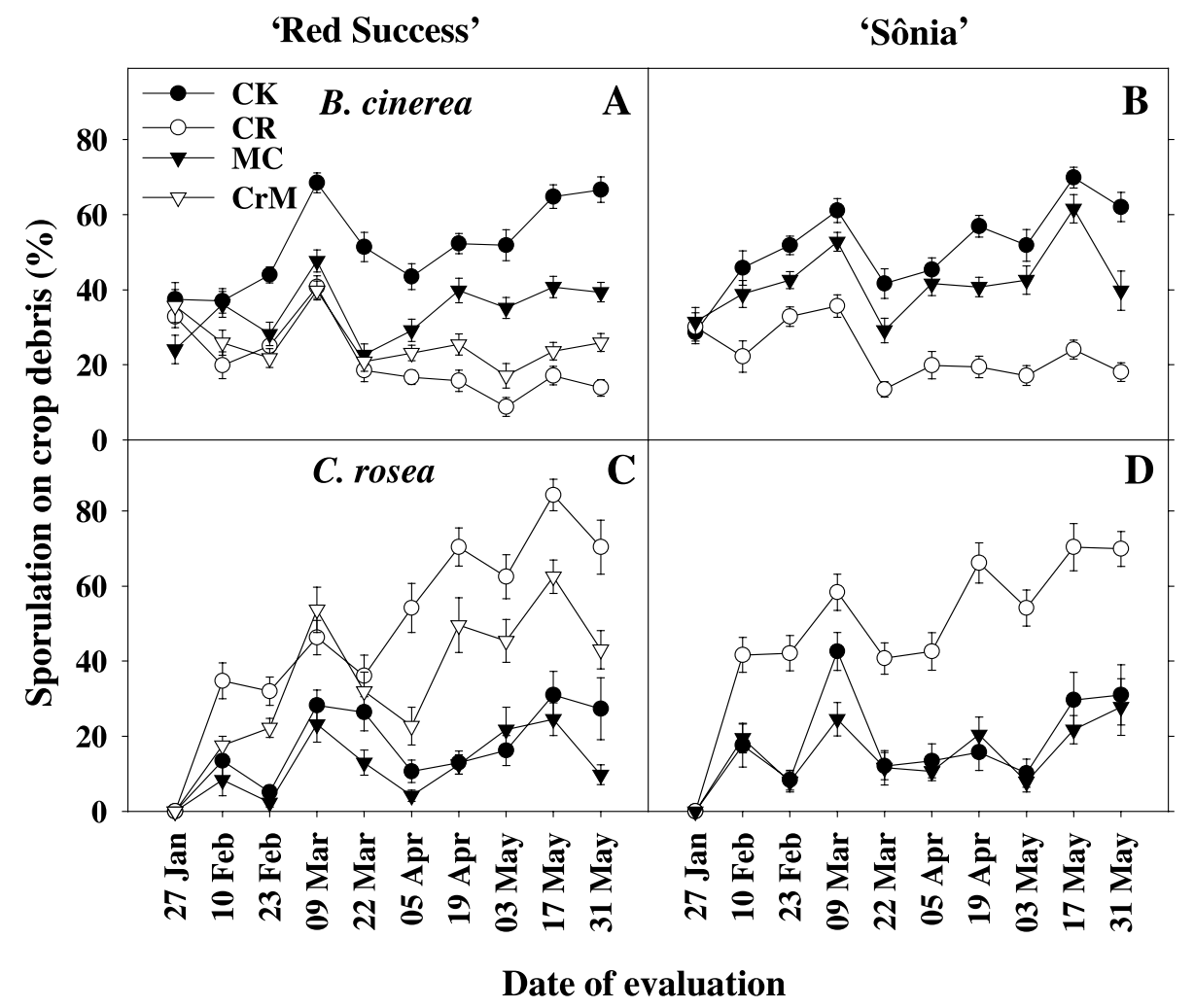

Fig. 2. Intensity of B. cinerea and C. rosea sporulation on petal and leaf disks from rose debris treated with C. rosea applied biweekly (Cr), mancozeb applied weekly (MC), C. rosea and mancozeb applied in alternate weeks (CrM), and a water control (CK). The samples were taken at 13-15 day intervals. (A and B) B. cinerea on cv. 'Red Success' and 'Sonia,' respectively; (C and D) C. rosea on cv. 'Red Success' and 'Sonia,' respectively. The treatment CrM was not applied on 'Sonia.' Curves show mean values with standard error bars. 


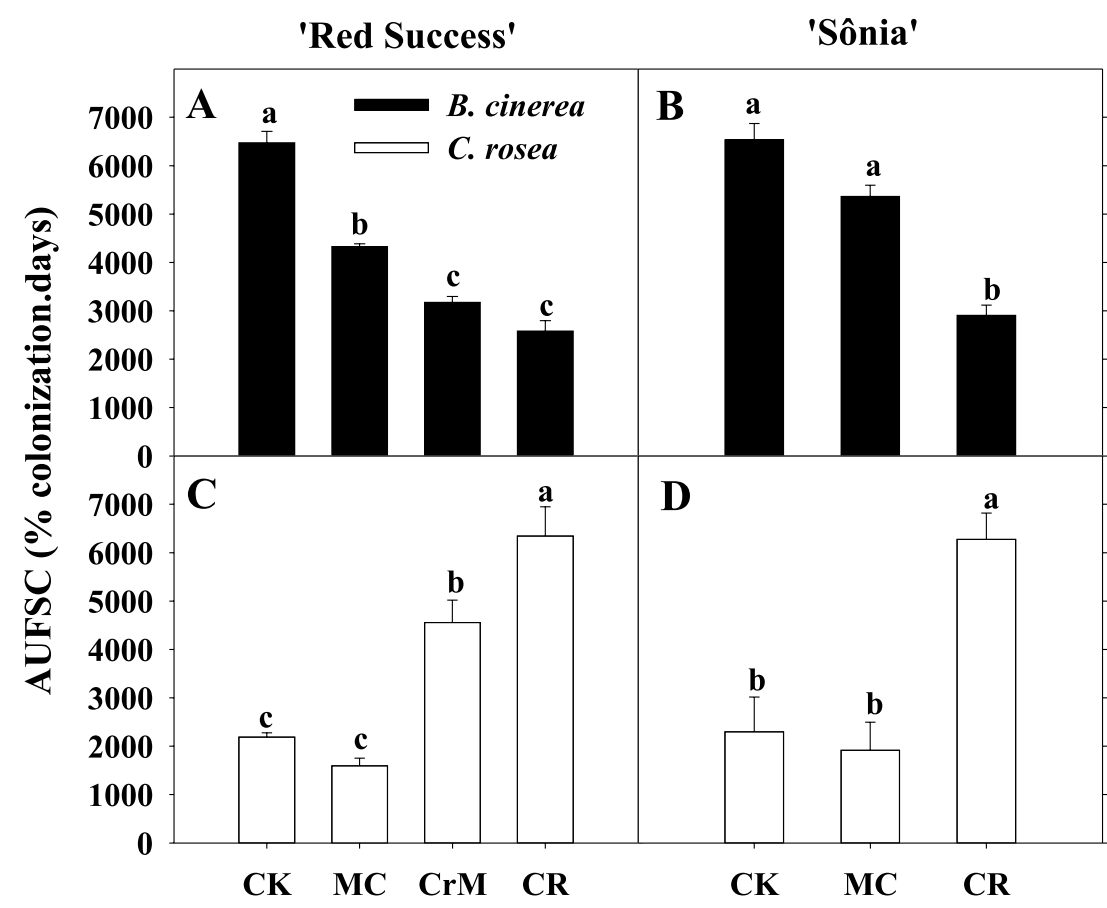

Fig. 3. Area under fungus sporulation curve (AUFSC) of B. cinerea and C. rosea on rose debris treated with $C$. rosea applied biweekly (Cr), mancozeb applied weekly (MC), C. rosea and mancozeb applied in alternate weeks (CrM), and a water control (CK). The samples were taken at 1315 day intervals. (A and B) AUFSC of B. cinerea on cv. 'Red Success' and 'Sonia,' respectively; (C and D) AUFSC of $C$. rosea on cv. 'Red Success' and 'Sonia,' respectively. The treatment CrM was not applied for 'Sonia.' Data bars are mean values each with a standard error bar. Treatment means followed by the same letter are not significantly different (Protected LSD, $P \leqslant 0.05$ ).

recovered sporadically and in minor amounts on the control plots $(\mathrm{CK})$ and on plots treated with mancozeb (MC) (Figs. 2C and D). As C. rosea was not detected in the greenhouse before the experiment was initiated, contamination from the treated plots possibly occurred.

\subsection{Botrytis blight incidence on rose buds}

The incidence of Botrytis blight on rose buds of both cultivars in the experimental plots before the treatment applications ranged from 62 to $100 \%$. The $\mathrm{Cr}$ and $\mathrm{CrM}$ treatments significantly reduced (PLSD, $P \leqslant 0.05$ ) disease incidence on five of eight sample dates for 'Red Success' (Table 1). The MC treatment was efficient only on three sample dates. For 'Sonia,' the $\mathrm{Cr}$ treatment reduced the disease significantly only on two sampling dates and the MC on none (Table 1). However, in all cases the reduction of Botrytis blight incidence was not superior to $25 \%$ in relation to the control plots.

Table 1

Botrytis blight incidence (\%) on rose buds of cv. 'Red Success' and 'Sonia' on eight sample dates from January 25 th to May 10 th of 2000

\begin{tabular}{|c|c|c|c|c|c|c|c|}
\hline \multirow[t]{2}{*}{ Sample date } & \multicolumn{4}{|c|}{ 'Red Success' } & \multicolumn{3}{|c|}{ 'Sonia' } \\
\hline & $\mathrm{CK}$ & $\mathrm{Cr}$ & $\mathrm{MC}$ & $\mathrm{CrM}$ & $\mathrm{CK}$ & $\mathrm{Cr}$ & $\mathrm{MC}$ \\
\hline $1^{\mathrm{a}}$ & 72.0 & 73.1 & 80.9 & 81.9 & 81.8 & 79.7 & 81.5 \\
\hline 2 & 86.7 & $75.0^{\mathrm{b}}$ & 83.3 & $70.0^{\mathrm{b}}$ & 70.0 & 76.7 & 71.7 \\
\hline 3 & 96.7 & $81.7^{\mathrm{b}}$ & $83.3^{\mathrm{b}}$ & $85.0^{\mathrm{b}}$ & 98.3 & 91.7 & 88.3 \\
\hline 4 & 91.1 & 82.0 & 88.9 & 85.2 & 93.3 & 81.7 & 83.3 \\
\hline 5 & 93.3 & $75.0^{\mathrm{b}}$ & $86.7^{\mathrm{b}}$ & $81.7^{\mathrm{b}}$ & 91.7 & 78.3 & 81.7 \\
\hline 6 & 93.3 & $81.7^{\mathrm{b}}$ & 91.7 & $80.0^{\mathrm{b}}$ & 93.3 & $76.7^{\mathrm{b}}$ & 86.7 \\
\hline 7 & 91.7 & $80.0^{\mathrm{b}}$ & $81.7^{\mathrm{b}}$ & $78.3^{\mathrm{b}}$ & 95.0 & $68.3^{\mathrm{b}}$ & 85.0 \\
\hline 8 & 93.3 & 81.7 & 91.7 & 85.0 & 96.7 & 81.7 & 95.0 \\
\hline
\end{tabular}

$\mathrm{Cr}$, application of C. rosea biweekly; MC, application of mancozeb weekly at the ratio of $200 \mathrm{~g}$ c.f. per 100 liter of water; CrM, application of $C$. rosea and mancozeb in alternate weeks; and CK, water control.

${ }^{\text {a }}$ Prior to treatment applications.

${ }^{\mathrm{b}}$ Significantly different values in relation to the control on the same sample date (PLSD, $P \leqslant 0.05$ ). 


\section{Discussion}

Necrotrophic, nonspecialized pathogens such as $B$. cinerea infect healthy plant tissues but the mycelial growth and sporulation occur only after the senescence of the tissues (Köhl et al., 1995). Thus, rose debris inside the greenhouse is the main inoculum source of the pathogen (Araújo et al., 1995). Because the progress of Botrytis blight epidemics on rose production systems depends chiefly on the inoculum produced inside the greenhouse (Monteiro et al., 1996), the use of an antagonist that competes efficiently with the saprophytic growth and sporulation of the pathogen is a valid control strategy (Köhl and Fokkema, 1998). However the effectiveness of $C$. rosea against $B$. cinerea is directly related to the capacity of the antagonist to colonize host senescent tissues faster than the pathogen (Morandi et al., 2001; Morandi et al., 2000a). Thus, the developmental stage of the host tissue, the microbial community associated with the debris, and the microclimatic conditions during the colonization events are factors that determine the success of $C$. rosea and other antagonists as biological control agents of B. cinerea (Guetsky et al., 2001; Morandi et al., 2001; Sutton et al., 1997; Yu and Sutton, 1997).

In our study, C. rosea established efficiently on rose debris as verified by the increment of its sporulation at each sample date, the high values of AUFSC, and the reduction of $B$. cinerea sporulation on the plots treated with the biocontrol agent. Other evidence of the successful establishment of $C$. rosea on rose debris was the recovery of the fungus from the nontreated plots. Before application in the greenhouse, C. rosea was not detected in soil and debris samples. It is reasonable to suppose that the isolation of C. rosea on the CK and MC plots resulted from contamination that originated in plots treated with the antagonist. The occurrence of drift during $C$. rosea application could also explain the contamination of CK and MC plots. However, this is not likely the main reason for the contamination, as the fungal suspension was sprayed with a low-pressure hand sprayer directed toward the surface of the rose beds and with a relative low volume of suspension per area $\left(0.1 \mathrm{liter} / \mathrm{m}^{2}\right)$. Most likely, the contamination was caused by conidia of $C$. rosea produced within the treated plots and carried to the other plots by the irrigation water. This hypothesis is corroborated by the fact that the contamination occurred initially and predominantly on the plots located adjacent to and downward from those treated with the antagonist.

The successful establishment of $C$. rosea, notwithstanding conditions favorable to Botrytis blight development inside the greenhouse, reinforces prior reports that environmental requirements for $C$. rosea and $B$. cinerea are similar (Morandi et al., 2001). This finding can be of paramount importance when establishing a biocontrol strategy against the pathogen, as $C$. rosea could be effectively applied to reduce $B$. cinerea sporulation not only in marginal situations but also under conditions favorable to the pathogen. As already indicated, our data stress the importance of understanding the ecological attributes of the biocontrol agent to prevent its failure (Guetsky et al., 2001; Köhl and Fokkema, 1994; Köhl et al., 1999; Shtienberg and Elad, 1997; Sutton et al., 1997).

Compared to the control, weekly applications of mancozeb moderately affected pathogen sporulation on 'Red Success' and did not affect sporulation on 'Sonia' plants. Under high inoculum pressure, the efficiency of fungicides to control B. cinerea is reduced (Gullino, 1992; Monteiro et al., 1996; Hausbeck and Moorman, 1996). In our study, the use of alternate applications of mancozeb with $C$. rosea did not increase the efficiency of the antagonist against $B$. cinerea. This was probably due to the noticeable reduction of $C$. rosea growth on these plots. In a previous study, Morandi et al. (1996) reported up to $40 \%$ reduction of mycelial growth and sporulation of $C$. rosea on agar medium containing mancozeb.

Despite the reduction of $B$. cinerea sporulation on the treated plots, Botrytis blight incidence on rose buds was not consistently reduced, probably due to three main reasons: (i) the applications of $C$. rosea were begun by the end of January when Botrytis blight epidemic was advanced; (ii) no sanitation practices were performed during the experiment; and (iii) the production of $B$. cinerea inoculum was found on the nontreated border plants.

Most studies that have indicated high efficacy of biocontrol agents were conducted under controlled conditions. It has been suggested that environmental conditions that are not fully controlled in commercial productions systems might influence the survival, establishment, and activity of the biocontrol agents (Burrage, 1971; Hannush and Boland, 1996) and consequently reduce the efficacy of biological control. However, according to our results, $C$. rosea was able to establish on rose tissues and reduce $B$. cinerea sporulation in a commercial greenhouse without climatic control. Accordingly, the present and previous studies indicate that continuous applications of $C$. rosea, associated with sanitation practices, can be expected to markedly reduce inoculum production by $B$. cinerea and consequently Botrytis blight incidence on rose buds.

\section{Acknowledgments}

This article was part of a Ph.D. dissertation of the first author. He was supported by a scholarship provided by the Brazilian Coordination of Training of Higher Education Graduate (CAPES). The research was 
partially founded by CNPq ('Conselho Nacional de Desenvolvimento Científico e Tecnológico') and FAPEMIG ('Fundação de Apoio à Pesquisa do Estado de Minas Gerais'). This paper was partially founded by FAPESP ('Fundação de Amparo à Pesquisa do Estado de São Paulo').

\section{References}

Araújo, A.E., Maffia, L.A., Alfenas, A.C., Capdeville, G., Barreto, R.W., 1995. [Gray mold progress on roses growing under greenhouse] Progresso do mofo cinzento em roseiras cultivadas em casa de vegetação. Fitop. Bras. 20, 341 (abs).

Burrage, S.W., 1971. The micro-climate at the leaf surface. In: Preece, T.E., Dickinson, C.H. (Eds.), Ecology of Leaf Surface Microorganisms. Academic Press, London, pp. 91-101.

Elad, Y., 1988. Latent infection of Botrytis cinerea in rose flowers and combined chemical and physiological control of the disease. Crop Prot. 7, 361-366.

Guetsky, R., Shtienberg, D., Elad, Y., Dinoor, A., 2001. Combining biocontrol agents to reduce the variability of biological control. Phytopathology 91, 621-627.

Gullino, M.L., 1992. Chemical control of Botrytis spp. In: Verhoeff, K., Malathrakis, N.E., Williamson, E.B. (Eds.), Recent Advances in Botrytis Research. PUDOC, Wageningen, pp. 217-222.

Hannush, J.D., Boland, G.J., 1996. Interactions of air temperature, relative humidity and biological control agents on grey mould of bean. Eur. J. Plant Pathol. 102, 133-142.

Hausbeck, M.K., Moorman, G.W., 1996. Managing Botrytis in greenhouse-grown flower crops. Plant Dis. 80, 1211-1219.

Horst, R.K., 1983. Compendium of Rose Diseases. The American Phytopathological Society, St. Paul, MN.

Köhl, J., Fokkema, N.J., 1994. Fungal interactions on living and necrotic leaves. In: Blakeman, J.P., Williamson, B. (Eds.), Ecology of Plant Pathogens. CABI, Oxon, pp. 321-334.

Köhl, J., Fokkema, N.J., 1998. Strategies for biological control of necrotrophic fungal pathogens. In: Boland, G.J., Kuykendall, L.D. (Eds.), Plant-Microbe Interactions and Biological Control. M. Dekker Inc., New York, pp. 49-88.

Köhl, J., Lombaers-Van Der Plas, C.H., Molhoek, W.M.L., Kessel, G.J.T., Goossen-Van Der Geijn, H.M., 1999. Competitive ability of the antagonists Ulocladium atrum and Gliocladium roseum at temperatures favorable for Botrytis spp. development. BioControl 44, 329-346.

Köhl, J., Molhoek, W.M.L., Van Der Plas, C.H., Fokkema, N.J., 1995. Supression of sporulation of Botrytis spp. as a valid biocontrol strategy. Eur. J. Plant Pathol. 101, 251-259.
Monteiro, A.J.A., Maffia, L.A., Morandi, M.A.B., Tatagiba, J.S., 1996. [Effects of debris removal on spore dispersal and gray mold intensity in roses growing under greenhouse] Efeito da remoção de restos culturais na quantidade de esporos no ar e na intensidade do mofo cinzento em roseiras cultivadas em casa de vegetação. Fitop. Bras. 21, 403 (abs.).

Morandi, M.A.B., Maffia, L.A., Sutton, J.C., 2001. Development of Clonostachys rosea and interactions with Botrytis cinerea in rose leaves and residues. Phytoparasitica 29 (2), 103-113.

Morandi, M.A.B., Maffia, L.A., Monteiro, A.J.A., Tatagiba, J.S., 1996. [Effects of fungicides on mycelial growth of biocontrol agents against Botrytis cinerea] Efeito de fungicidas sobre o crescimento micelial de agentes de biocontrole para Botrytis cinerea. Fitop. Bras. 21, 373 (abs.).

Morandi, M.A.B., Sutton, J.C., Maffia, L.A., 2000a. Relationships of aphid and mite infestations to control of Botrytis cinerea by Clonostachys rosea in rose (Rosa hybrida) leaves. Phytoparasitica 28, 55-64.

Morandi, M.A.B., Sutton, J.C., Maffia, L.A., 2000b. Effects of host and microbial factors on development of Clonostachys rosea and control of Botrytis cinerea in rose. Eur. J. Plant Pathol. 106, 439-448.

Peng, G., Sutton, J.C., 1991. Evaluation of microorganisms for biocontrol of Botrytis cinerea in strawberry. Can. J. Plant Pathol. $13,247-257$.

Schroers, H.J., Samuels, G.J., Seifert, K.A., Gams, W., 1999. Classification of the mycoparasite Clonostachys rosea in Clonostachys as C. rosea, its relationship to Bionectria ochroleuca, and notes on other Gliocladium-like fungi. Mycologia 91, 365-385.

Shtienberg, D., Elad, Y., 1997. Incorporation of weather forecasting in integrated, biological-chemical management of Botrytis cinerea. Phytopathology 87, 332-340.

Snedecor, G.W., Cochran, W.G., 1989. Statistical Methods, eighth ed. The Iowa State University Press, Ames.

Snyder, R.S., Shaw, R.H., 1984. Converting humidity expressions with computers and calculators. Univ. Calif. Coop. Ext. Leafl. 21372.

Sosa-Alvarez, M., Madden, L., Ellis, M.A., 1995. Effects of temperature and wetness duration on sporulation of Botrytis cinerea on strawberry leaf residues. Plant Dis. 79, 609-615.

Sutton, J.C., Peng, G., 1993. Biocontrol of Botrytis cinerea in strawberry leaves. Phytopathology 83, 615-621.

Sutton, J.C., Li, D.-W., Peng, G., Yu, H., Zhang, P., ValdebenitoSanhueza, R.M., 1997. Gliocladium roseum, a versatile adversary of Botrytis cinerea in crops. Plant Dis. 81, 316-328.

Tatagiba, J.S., Maffia, L.A., Barreto, R.W., Alfenas, A.C., Sutton, J.C., 1998. Biological control of Botrytis cinerea in residues and flowers of rose (Rosa hybrida). Phytoparasitica 26, 8-19.

Yu, H., Sutton, J.C., 1997. Morphological development and interactions of Gliocladium roseum and Botrytis cinerea in raspberry. Can. J. Plant Pathol. 19, 237-246. 